\title{
Production, settlement, and survival of plexaurid gorgonian recruits
}

\author{
Howard R. Lasker*, Kiho Kim**, Mary Alice Coffroth \\ Department of Biological Sciences, State University of New York at Buffalo, PO Box 601300, Buffalo, \\ New York 14260-1300, USA
}

\begin{abstract}
Observed recruitment rates among benthic invertebrates reflect a cascade of events that starts with the production of gametes and includes fertilization, settlement and the mortality that occurs shortly after settlement. Although recruitment rates are commonly measured, studies that include the steps leading to recruitment are relatively rare. Fecundity, fertilization rates, larval supply, post-settlement mortality and annual recruitment of the clonal gorgonian Plexaura kuna were determined for a population in the San Blas Islands, Panama. Fecundity of colonies was determined by enumerating the eggs contained within polyps of female colonies and from the number of eggs released in aquaria by colony explants. On average, colonies released 23.2 eggs $\mathrm{cm}^{-1}$ of branch length. Polyps on second order branches contained more eggs than those on primary or tertiary branches. Extrapolation of egg release data as well as the density of eggs in the water column during spawning suggests that genets, which may contain $10^{2}$ colonies, can produce $10^{6}$ to $10^{7}$ eggs annually. Only 1 planula was observed in a total of 40 settlement traps that were sampled weekly during June and July 1989 . To assess post-settlement survival, planulae of $P$. kuna were reared and allowed to settle on 40 seasoned Plexiglas plates which were then returned to the reef. Mortality during the first $2 \mathrm{wk}$ on the reef was $60 \%$. Survivorship was greatest on the most protected section of the Plexiglas plates, and when the entire settlement plate was floated above the substratum and away from benthic grazers. Monthly recruitment of $P$. kuna was monitored in $2 \mathrm{~m}^{2}$ areas at 3 sites between June 1986 and July 1988. Few recruits were observed and all died within several months of their appearance in the survey areas. Annual recruitment was followed in $230 \mathrm{~m}^{2}$ during 1984 to 1996 . At one site, $P$. kuna recruits were not observed, and at the other 2 sites, recruitment rates were 0.04 and $0.002 \mathrm{~m}^{-2} \mathrm{yr}^{-1}$ Extrapolations of colony production rates, clone size, and post-settlement survival suggest that recruitment is most sensitive to survival of larvae in the water column and survival of newly settled individuals. The 3 -fold difference in mortality rates on different areas of the settlement plates leads to a 100 -fold difference in recruitment. Although recruitment rates are low when considered on an annual basis, clonal propagation, which extends genet lifespan over many decades, dramatically increases the likelihood of successful settlement over the lifespan of colonies and genets.
\end{abstract}

KEY WORDS: Coral reef $\cdot$ Recruitment $\cdot$ Population dynamics $\cdot$ Fertilization $\cdot$ Octocoral

\section{INTRODUCTION}

Recruitment is often portrayed as the starting point in the events structuring benthic community dynamics. However, recruitment is not a single event but the product of a series of independent processes. The cas-

\footnotetext{
-E-mail: hlasker@acsu.buffalo.edu

- Present address: Section of Ecology and Systematics, Corson Hall, Cornell University, Ithaca, New York 14853-2701, USA
}

cade of events leading to successful recruitment includes gamete production, fertilization, survival in the water column, settlement and early survival of newly settled individuals. Over the last decade, many of these steps have been examined in the contexts of larval ecology (Young 1990) and fertilization processes (Levitan \& Petersen 1995). Analytic approaches to modeling these processes have also been discussed (Eckman 1996). Nonetheless, data on larval production and ecology of many ecologically important taxa are still unavailable. Even among well-studied species, 
analyses that quantify all or most of these steps are relatively rare. For instance, although coral reef gorgonians are among the most abundant taxa of the Caribbean fauna, we know relatively little about their rates of recruitment or settlement and have no information on the survival of those larvae that settle and metamorphose.

Studies examining recruitment processes have frequently focused on the differences between settlement and recruitment. Recognition of these differences has played an important role in our understanding of a variety of benthic taxa and communities. For instance, Grosberg (1982), Wethey (1984), Connell (1985), and Gaines \& Roughgarden (1985) documented the importance of initial settlement patterns on zonation of adult barnacles in the intertidal. Among subtidal species post-settlement mortality plays a large role in population and community dynamics, and in some cases postsettlement mortality alters recruitment patterns from those predicted on the basis of settlement alone (Keough \& Dawnes 1982, Connell 1985, Keough \& Chernoff 1987, Yund et al. 1987, Davis 1988, Hurlbut 1991). Although factors such as settlement cues may prevent benthic species from settling in completely inhospitable environments, much of the small scale variance in the distribution of many species may be determined by variance in post-settlement survivorship.

Examination of the earlier steps in the recruitment process has been uncommon. Data on population fecundity are often gathered in the context of life history studies, but because marine populations are generally viewed as open systems, there has been little interest in characterizing spatial and temporal variation in fecundities. Recently, there has been a recognition that fertilization processes may be limiting among some species and in some habitats (Pennington 1985 , Brazeau \& Lasker 1992, Levitan 1995, Levitan \& Petersen 1995, Lasker et al. 1996a).

Independent of the effects on local species abundance, differential fecundities, fertilization, and survival all create strong selection pressures within species. Traits such as egg size have been hypothesized to be subject to selection for enhancing fertilization (Levitan 1993). Similarly, traits that enable larvae to settle in habitats that enhance their survival and ultimately enhance fecundity are likely under strong selection. Preferential settlement is a common feature of sessile benthic invertebrates, and, to date, a number of settlement cues have been identified, including hydrodynamic conditions (Wethey 1986, Eckman 1987, 1990, Mullineaux 1989, Butman et al. 1992, Mullineaux \& Garland 1993), substrate heterogeneity (Chabot \& Bourget 1988, Eckman 1990), and a range of chemicals (Morse 1990, Pawlik \& Toonen 1992, Morse et al. 1994, 1996). The effects of settlement cues probably range from simply identifying the right habitat (e.g. hard substratum versus soft, shallow versus deep water) to identifying microhabitats that maximize survival.

Studies of recruitment processes among coral reef taxa have been less common than in intertidal and fouling communities because many reef taxa are longlived and have low recruitment rates (Table 1). Thus, the life history strategies of many reef taxa are not conducive to ecological analysis on the scale of only a few years. The available data suggest that patterns of distribution and abundance could very well be driven by recruitment processes that vary on scales of many years. Preferential recruitment and/or settlement has been reported for some reef corals (Coles 1984, Carlon \& Olson 1993, Morse et al. 1994, Babcock \& Mundy 1996). In situ fertilization rates can vary between 0 and

Table 1 Recruitment rates of scleractinians and octocorals on natural and artuficial substrata. Only studies with species level identification are presented. GBR: Great Barrier Reef, Australia

\begin{tabular}{|c|c|c|c|c|c|}
\hline Species & Location & $\begin{array}{l}\text { Settlement } \\
\text { substrate }\end{array}$ & $\begin{array}{c}\text { Settlement } \\
\text { (recruits } \mathrm{m}^{-2} \text { ) }\end{array}$ & $\begin{array}{l}\text { Duration } \\
\text { of study }\end{array}$ & Source \\
\hline Platygyra sinesıs & GBR & Reef & 0.13 & $12 \mathrm{mo}$ & Babcock (1991) \\
\hline Goniastrea aspera & GBR & Reef & 0.26 & $12 \mathrm{mo}$ & Babcock (1991) \\
\hline Goniastrea favulus & GBR & Reef & 0.4 & $12 \mathrm{mo}$ & Babcock (1991) \\
\hline Agaricia agricites & Barbados & Tiles & 4.3 & $17 \mathrm{mo}$ & Hunte \& Wittenberg (1992) \\
\hline Siderastred radians & Bermuda & Tiles & 7.4 & $12 \mathrm{mo}$ & Smith (1992) \\
\hline Favia fragum & Bermuda & Reef & 8.7 & $12 \mathrm{mo}$ & Smith (1992) \\
\hline Porites astreoides & Jamaica & Coral skeleton & 34.2 & $10 \mathrm{mo}$ & Rylaarsdam (1983) \\
\hline Porites astreoides & Bermuda & Tiles & 377.4 & $4 \mathrm{mo}$ & Smith (1992) \\
\hline Balanophyllia elegans & California & Reef & 500 & $12 \mathrm{mo}$ & Fadlallah (1.983) \\
\hline Efflatounaria sp. & GBR & Reef & $0.37^{\circ}$ & $4 \mathrm{mo}$ & Karlson et al. (1996) \\
\hline Efflatounaria sp. & GBR & Coral skeleton & 2.6 & $12 \mathrm{mo}$ & Fabricius (1995) \\
\hline
\end{tabular}


$100 \%$ across days, months, and years among some gorgonians (Brazeau \& Lasker 1992, Lasker et al. 1996a). Furthermore, recruitment rates measured shortly after settlement can be dramatically higher than those measured later in the year, suggesting the importance of early, post-settlement mortality. Understanding these different processes is essential to understanding recruitment rates and the evolution of life history traits that affect recruitment. In this report we present data documenting low and variable recruitment rates for a Caribbean gorgonian and show how the processes of gamete production, fertilization, and early survival of newly settled planulae contribute to the magnitude of, and variance in, recruitment.

\section{METHODS}

The research was conducted on the gorgonian Plexaura kuna Lasker, Kim \& Coffroth (Lasker et al. 1996b), on reefs in the vicinity of the Smithsonian Tropical Research Institute (STRI) field station in the San Blas Islands, Panama. Gorgonians are common members of the fauna on these reefs. On many reefs, gorgonians are the dominant taxon, and $P$. kuna is among the most common species (Lasker et al. 1988). On those reefs where $P$. kuna is locally abundant, its success is driven by vegetative propagation (Lasker 1990, Coffroth \& Lasker 1998). Although most colonies are derived from fragmentation, all of the reefs we have surveyed contain multiple genotypes, and no single genotype is found on more than 1 reef (Lasker \& Coffroth 1985, Coffroth et al. 1992, Coffroth \& Lasker 1998). Those observations indicate that sexual reproduction and the resultant recruitment of planula larvae does occur and is essential to the spread of the species between reefs. Sexual reproduction occurs during synchronous spawning events during the summer months (Brazeau \& Lasker 1989). Starting $3 \mathrm{~d}$ after the full moon, P. kuna colonies release eggs and sperm in nightly events that start shortly after sunset and last for approximately $60 \mathrm{~min}$. That pattern is repeated for 4 to 6 nights during each month from mid-May through September. The predictability of these events greatly facilitates the measurements of egg production, fertilization, and settlement.

Production. Fecundity of 20 marked Plexaura kuna colonies (KP1, KP2, ... KP20) from Korbiski Reef (San Blas Islands) was measured during 1990 by quantifying the numbers of eggs released from colony explants (i.e. branches) maintained in aquaria at the STRI field station. Several days before the full moon, one 15 to $25 \mathrm{~cm}$ long branch was excised from each marked colony and transported to the station, where branches were kept in 201 aquaria. The branches had total linear lengths, i.e. the sum of the main branch and subbranch lengths, which were substantially greater than 15 to $25 \mathrm{~cm}$, ranging from 50 to $290 \mathrm{~cm}$. The water in the aquaria was vigorously exchanged at $2 \mathrm{~h}$ intervals during daylight hours and twice during the night. During nights of spawning, water was exchanged before spawning (18:00 h) and well after spawning (23:00 h). On nights of spawning, all released eggs were removed from the tank and counted. At the end of the spawning event, total linear length of each branch was measured, and the number of eggs released was then adjusted for the total linear length of that branch. The 20 colonies were sampled during July, August and September, and different branches were used each month. In August, replicate branches (1 per colony) of 9 of the colonies were also monitored. Samples were not collected in June, which probably also was a spawning month, but Brazeau \& Lasker (1989) presented data indicating that spawning among colonies at Korbiski Reef is low during the first and last month of active spawning. Egg release after the lateMay/early-June full moon is relatively low (Brazeau \& Lasker 1989, authors' pers. obs.) and the egg production that was not measured in June 1990 was probably similar to that of September.

As colony-level fecundity may also be affected by variation between polyps at different locations (Brazeau \& Lasker 1990), we examined numbers of eggs from branches at different positions in the colony. Branches consisting of a number of branch tips were collected from 6 female colonies ( 1 branch per colony) at Korbiski and Aguadargana Reefs (San Blas Islands) in June 1990. On each branch, 3 branch tips were arbitrarily chosen and the numbers of eggs were determined by dissecting groups of 10 polyps from within fixed $1 \mathrm{~cm}$ long sections. Branch position was classified as in Brazeau \& Lasker (1988), and each position was sampled as follows: primary $\left(1^{\circ}\right)$ branches $-1 \mathrm{~cm}$ from the branch tip and $2 \mathrm{~cm}$ above the first branch point; second order $\left(2^{\circ}\right)$ branches $-2 \mathrm{~cm}$ below the branch junction creating the $2^{\circ}$ branch; third order branches$2 \mathrm{~cm}$ below the branch junction creating the $3^{\circ}$ branch.

In 1995, we estimated egg production of a Plexaura kuna clone at Korbiski Reef by measuring the density of eggs in the water column downstream of that clone. During each of 11 spawning nights, photographs of eggs in the water column were taken with a Nikonos $\mathrm{V}$ camera attached to and pointing at a black Plexiglas board at a distance of $1 \mathrm{~m}$. Photographs were taken at 15 min intervals. During each interval, photographs were taken at 3 locations in the water column: just above the substratum (bottom); approximately $1.5 \mathrm{~m}$ above the substratum (mid-depth); and within the upper $0.5 \mathrm{~m}$ of the water column (surface). Water depth at the site was 2 to $3 \mathrm{~m}$. Photographs were taken on the 
downstream side of the clone, which measures $8 \mathrm{~m}$ across. Because the clone we monitored is the largest at Korbiski Reef ( 800 colonies), even eggs floating near the surface should be predominantly from that clone. All eggs that appeared against the backdrop of the board were counted, and density of the eggs was determined by correcting for the volume, assuming that all eggs between 0.5 and $1 \mathrm{~m}$ from the camera lens were sufficiently distinct for counting. The $0.5 \mathrm{~m}$ depth of field was determined by examination of $1 \mathrm{~mm}$ dots photographed at measured distances from the camera. Current speed during the spawning event was recorded by an $\$ 4$ current meter which sampled at $0.5 \mathrm{~s}$ intervals.

Fertilization. Fertilization rates of eggs released at Korbiski were estimated by collecting eggs and incubating them overnight to determine the proportion that developed into embryos. The large, $>500 \mu \mathrm{m}$, eggs were collected during the spawning events by divers using $60 \mathrm{ml}$ syringes. Samples collected between 1993 and 1996 were collected along $10 \mathrm{~m}$ transects placed perpendicular to the current and downstream of the spawning colonies. Details of the sampling routine and technique are presented in Lasker et al. (1996a). The number of developing embryos in a given collection was used as an estimator of fertilization rates and converted into monthly weighted averages.

Larval supply. The supply of planulae to the reef was assessed by setting out 40 formalin filled 'larvae traps' at arbitrarily selected locations on Korbiski Reef. The traps were a modification of those described by Yund et al. (1991). Each $60 \mathrm{~cm}$ long, $5 \mathrm{~cm}$ diameter polybutyrate tube was attached to a vertical stand, and $50 \mathrm{ml}$ of $100 \%$ formalin and rose bengal was injected into the base of the tube through a port sealed with a Vacutainer stopper The stain and formalin formed a layer at the bottom of the tube and, due to its greater density, the formalin remained in the tube throughout the week long deployment. Tubes were capped after $1 \mathrm{wk}$ and transported back to the field station. The formalin solution was filtered through $250 \mu \mathrm{m}$ mesh, which was examined for the presence of planulae. Traps were monitored at 7 weekly intervals during June and July 1989. Larval traps sample in proportion to both the horizontal and vertical flux of larvae, and, at least for some taxa, appear to yield data that are highly correlated with settlement rates (Yund et al. 1991).

Settlement/recruitment. Recruitment was monitored at Korbiski, Macaroon, and Pinnacles Reefs (San Blas Islands). [Reefs are identified as Korbiski-1SE, Porvenir-26 and Pico Feo-14 in Fig. 1 of Robertson (1987)]. The reefs differed primarily in their exposure to waves and swell and to a lesser extent in depth and substratum characteristics. The reef at Korbiski is a back reef rising from silty sand at $15 \mathrm{~m}$ to a sandy reef flat at $<1 \mathrm{~m}$ depth. Gorgonians are common along the southeast face of the reef between 0.5 and $5 \mathrm{~m}$ depth and reflect the distribution of consolidated substrata. Gorgonians, especially Plexaura kuna, were most common in a $50 x$ $100 \mathrm{~m}$ area at the eastern edge of the reef and recruitment surveys were arbitrarily located within this area. Macaroon is located south of a channel through the barrier reef. The reef is 3 to $4 \mathrm{~m}$ deep and is a hardground that rises 1 to $2 \mathrm{~m}$ above the surrounding Thalassia spp. At the start of the study, the reef fauna was dominated by large colonies of the gorgonians Pseudoplexaura spp., most of which are now dead (Lasker unpubl. data). Pinnacles is an area of mixed sand and hard ground substrate surrounded by clumps of hard coral. Pseudoplexaura spp., Eunicea spp., Plexaura flexuosa and Plexaura homomalla were common on the hard substrata created by the scleractinians

Numbers of colonies recruiting to these 3 sites were monitored in 2 ways: during (1) monthly and (2) annual surveys of marked areas. In June 1986, two $0.5 \times 2 \mathrm{~m}$ areas were marked at each of the 3 reefs and carefully examined monthly for new recruits (i.e $<3 \mathrm{~cm}$ tall colonies that had not previously been observed). Colonies at this stage are extremely difficult to identify and we report their identities as probable Plexaura kuna recruits. Monthly intervals are distant enough that the values cannot be considered a settlement rate but they will more closely approximate settlement than annual censuses. Annual recruitment was monitored in two $0.5 \times 10 \mathrm{~m}$ transects at all 3 reefs from 1984 to 1996 and in $100 \mathrm{~m}^{2}$ areas at Pinnacles and Macaroon from 1986 to 1996. Surveys were conducted in the months of June, July or August. Spawning of the study species occurs during these same months and recruits observed in the survey were probably 1 year in age.

Post-settlement survivorship. Experiments were conducted during the summers of 1991 and 1995. Several days prior to spawning, male and female Plexaura kuna branches were collected and maintained separately in 20 laquaria at the STRI San Blas field station. On nights of spawning, eggs were collected from female tanks and mixed with water from male tanks and incubated overnight in either 1 or 0.51 polyethylene containers ( 100 to 500 eggs per container). Water in the containers was changed on the following morning and subsequent mornings until the larvae were 4 to $6 \mathrm{~d}$ old. Surviving planular larvae were pooled and divided into groups of 40 to 60 planulae and placed in wide mouth polyethylene containers along with $9 \mathrm{~cm}$ diameter Plexiglas settlement plates. The plates (Fig. 1) had a flat region on 2 sides (Zone A) and $0.6 \mathrm{~cm}$ tall ridges (Zone $R$ ) that created 3 additional zones between the ridges with widths of 0.5 (Zone $B$ ), 1.0 (Zone C), and $0.5 \mathrm{~cm}$ (Zone B). Lasker \& Kim (1996) showed that settlement rates are greater on substrata 

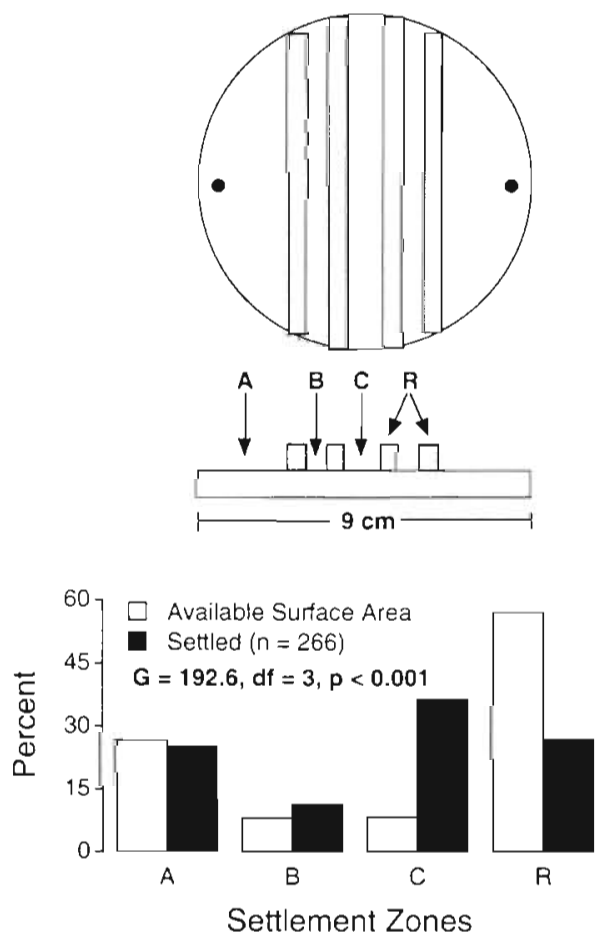

Fig. 1. Diagram of settling plate. A, B, C and $R$ refer to the different zones on the plate. For each zone, total surface area contained in that zone and the proportion of planulae $(n=$ 266) settled are given

with living cover (see also Harriott 1983, Sebens 1983, Benayahu \& Loya 1984, Morse et al. 1988). Consequently, the plates used in the experiments were initially placed out on the reef in April 1991. After a 2 mo conditioning period, the plates varied tremendously in the amount and type of cover. Encrusting coralline algae and macroalgae were the most obvious colonists. but tunicates, bryozoans and polychaetes were also present on some plates. Prior to their use in the experiments, plates were brushed in order to remove sediment and loosely bound organisms. Plates used in the 1995 experiments had been left on the reef in August 1991. As in the 1991 experiments, loosely attached and soft bodied epibionts were removed by brushing the plates prior to use. Planulae used in the 1995 experiments were 12 to $14 \mathrm{~d}$ old and a total of 75 planulae were added to each of 5 settlement containers.

Once planulae were added, approximately $50 \%$ of the water in the container was drained and replaced every other day. Care was taken during such exchanges to minimize stirring. The plates were maintained in this manner for $3 \mathrm{wk}$ ( $1 \mathrm{wk}$ in 1995) to allow for firm attachment of the newly settled polyps. In the 1991 experiments the plates were returned to their original sites, which were divided evenly between vertical and horizontal orientations. The plates were sur- veyed at weekly and monthly intervals after return to the field. In the 1995 experiments, the plates were floated in a vertical orientation $1 \mathrm{~m}$ above the substratum using a Styrofoam float and held to the bottom by a nylon monofilament line. Benthic grazers are unable to reach materials floated in this manner and browsers such as chaetodon fishes are also less likely to inspect these items (authors' pers. obs.).

\section{RESULTS \\ Production}

Different colonies had peak production in different months and on different days within months (Tables 2 \& 3). Gamete production by each colony peaked in a single month, but the differences between months are on the same scale as differences between replicate branches. This latter finding mirrors field observations in which some sections of a colony released copious numbers of eggs while adjacent, seemingly identical,

Table 2. Plexaura kuna. Egg release from coral branches taken from 20 colonies at Korbiski Reef and maintained in aquarla during the 1990 spawning events. All data have heen normalized to eggs released per linear $\mathrm{cm}$ of branch. [Each $\mathrm{cm}$ of branch contains 70 polyps $\mathrm{cm}^{-1}$ (Lasker 1990)]

\begin{tabular}{|c|c|c|c|c|}
\hline \multirow[t]{2}{*}{ Colony } & \multicolumn{4}{|c|}{ No. eggs released per $\mathrm{cm}$ of branch } \\
\hline & July & August & September & Total \\
\hline KP1 & 0.53 & 3.46 & 3.30 & 7.29 \\
\hline KP2 & 0.34 & $>12^{\mathrm{A}}$ & 0.61 & $>12.9^{a}$ \\
\hline KP3 & 0 & 3.35 & 1.55 & 4.90 \\
\hline KP4 & 6.87 & 0 & 1.28 & 8.15 \\
\hline KP5 & 7.15 & 2.21 & 0.14 & 9.50 \\
\hline KP6 & 8.54 & 0.55 & 0 & 9.09 \\
\hline KP7 & 0 & 0 & 0 & 0 \\
\hline KP8 & 0.15 & 22.1 & 0.92 & 23.1 \\
\hline KP9 & 21.8 & 1.17 & 0.05 & 23.0 \\
\hline KP10 & 36.9 & 7.67 & 0.12 & 44.7 \\
\hline KP11 & 3.96 & $>8^{a}$ & 2.41 & $>14.4^{a}$ \\
\hline KP12 & 0 & $>26^{\circ}$ & 1.59 & $>27.6^{\mathrm{d}}$ \\
\hline KP13 & 13.0 & 37.2 & 0 & 50.2 \\
\hline KP14 & 25.3 & $>1^{a}$ & 1.89 & $>28.1^{\mathrm{a}}$ \\
\hline KP15 & 0 & 0.60 & 0 & 0.60 \\
\hline KP16 & 43.4 & 7.70 & 0.14 & 51.2 \\
\hline KP17 & 12.8 & 40.0 & 0.76 & 53.6 \\
\hline KP18 & 0 & 22.7 & 0.39 & 23.1 \\
\hline KP19 & 0 & 24.1 & 0.64 & 24.7 \\
\hline $\mathrm{KP} 20$ & 0 & 54.0 & 0.19 & 54.2 \\
\hline \multicolumn{5}{|c|}{$\begin{array}{l}\text { 'Values marked as ' }>\text { ' were estimated in cases in which } \\
\text { branches were lost before we were able to measure the } \\
\text { total linear length. For these branches, eggs per linear cm } \\
\text { were calculated using the average size of the other } \\
\text { branches used in the experiments }\end{array}$} \\
\hline
\end{tabular}


Table 3. Plexaura kuna. Numbers of eggs released by coral branches taken from 20 colonies at Korbiski Reef and maintained in aquaria during the August 1990 spawning period. Egg release is given for each of 6 nights of spawning. Replicate branches of colonies are indicated by '-2' Mean egg release was calculated using the average of all branches. Total branch length and eggs $\mathrm{cm}^{-1}$ branch are not shown for branches which were lost before total linear branch length could be measured

\begin{tabular}{|c|c|c|c|c|c|c|c|c|c|}
\hline \multirow[t]{2}{*}{ Colony } & \multirow{2}{*}{$\begin{array}{l}\text { Total branch } \\
\text { length }(\mathrm{cm})\end{array}$} & \multicolumn{7}{|c|}{ No. of eggs released } & \multirow{2}{*}{$\begin{array}{c}\text { Eggs } \mathrm{cm}^{-1} \\
\text { branch }\end{array}$} \\
\hline & & Aug 8 & Aug 9 & Aug 10 & Aug 11 & Aug 12 & Aug 13 & Total & \\
\hline KP1 & 136.3 & 416 & 8 & 48 & 0 & 0 & 0 & 472 & 3.46 \\
\hline KP1-2 & 97.7 & 0 & 164 & 0 & 278 & 2 & 0 & 444 & 4.55 \\
\hline KP2 & & 0 & 455 & 2512 & 569 & 204 & 10 & 3750 & \\
\hline KP3 & 89.5 & 0 & 0 & 0 & 300 & 0 & 0 & 300 & 3.35 \\
\hline KP5 & 117.7 & 0 & 0 & 0 & 13 & 225 & 22 & 260 & 2.21 \\
\hline KPG & 217.2 & 111 & 8 & 0 & 0 & 0 & 0 & 119 & 0.55 \\
\hline KP7 & & 0 & 0 & 0 & 0 & 0 & 0 & 0 & 0 \\
\hline KP8 & 108.8 & 0 & 0 & 939 & 0 & 1350 & 113 & 2402 & 22.07 \\
\hline KP8-2 & 134.7 & 0 & 0 & 385 & 0 & 1000 & 18 & 1403 & 10.41 \\
\hline KPg & 95.1 & 0 & 0 & 32 & 67 & 12 & 0 & 111 & 1.17 \\
\hline KP10 & 101.6 & 0 & 20 & 341 & 337 & 81 & 0 & 779 & 7.67 \\
\hline $\mathrm{KP} 10-2$ & 99.8 & 0 & 0 & 117 & 240 & 292 & 51 & 700 & 7.01 \\
\hline KP11 & & 0 & 29 & 978 & 811 & 600 & 37 & 2455 & \\
\hline KP11-2 & & 0 & 0 & 141 & 331 & 600 & 248 & 1320 & \\
\hline $\mathrm{KP} 12$ & & 111 & 942 & 5108 & 1201 & 348 & 1 & 7711 & \\
\hline KP13 & 193.9 & 0 & 110 & 2999 & 300 & 3542 & 263 & 7214 & 37.20 \\
\hline KP13-2 & 95.9 & 0 & 0 & 349 & 700 & 1100 & 491 & 2640 & 27.53 \\
\hline KPI4 & & 0 & 11 & 90 & 47 & 0 & 0 & 148 & \\
\hline KP15 & 109.1 & 0 & 0 & 0 & 0 & 0 & 66 & 66 & 0.60 \\
\hline KP16 & 161.7 & 503 & 598 & 142 & 0 & 1 & 0 & 1244 & 7.69 \\
\hline $\mathrm{KP} 17$ & 52.7 & 0 & 244 & 1050 & 626 & 189 & 0 & 2109 & 40.04 \\
\hline KP17-2 & 110.7 & 56 & 476 & 400 & 442 & 246 & 11 & 1631 & 14.73 \\
\hline KP18 & 161.2 & 50 & 717 & 1.802 & 997 & 98 & 0 & 3664 & 22.73 \\
\hline KP18-2 & 173.6 & 0 & 208 & 800 & 650 & 221 & 0 & 1879 & 10.82 \\
\hline KP19 & 223.2 & 0 & 0 & 3326 & 1595 & 431 & 24 & 5376 & 24.08 \\
\hline KP19-2 & & 0 & 86 & 700 & 1050 & 500 & 39 & 2375 & \\
\hline KP2O & 293.4 & 0 & 0 & 4937 & 6009 & 4410 & 482 & 15356 & 53.99 \\
\hline KP20-2 & 142.3 & 0 & 0 & 851 & 851 & 1100 & 731 & 3533 & 24.83 \\
\hline Mean & & & & & & & & & 13.33 \\
\hline
\end{tabular}

branches released only a few eggs. Differences among colonies between months may be related to their genetic identity as Plexaura kuna is clonal (Lasker 1984,1990 ) and colonies used in the study were located in the areas on the reef occupied by 3 different female clones (Coffroth et al. 1992, Coffroth \& Lasker 1998). In situ observations made during spawning from 1986 through 1996 indicate 1 of the clones has peak production in June, a second in July, and a third in July and August. The temporal cycle within months indicates that most colonies exhibited greatest egg production on Days 5 and 6 following the full moon (the full moon is counted as Day 1 ).

Numbers and volumes of eggs within polyps were extremely variable between polyps, branches of different order, and between colonies. Number of eggs per polyp (mean $\pm \mathrm{SE}$ ) for the different branch orders were $1^{\circ}=1.41 \pm 0.05,2^{\circ}=1.97 \pm 0.08$, and $3^{\circ}=1.6 \pm 0.08$. Volume of eggs per polyp (in $\mathrm{mm}^{3}$ ) for the different branch orders were: $1^{\circ}=0.0011 \pm 0.0001,2^{\circ}=0.0017 \pm$ 0.0001 , and $3^{\circ}=0.0015 \pm 0.0001$. Because these data were heteroscedastic and could not be transformed appropriately, they were analyzed with non-parametric statistics. Kruskal-Wallis tests indicated that there were significant differences in both the number and volume of eggs per polyp between different colonies $(p<0.0001)$ and branch orders $(p<0.0001)$.

The density of eggs was determined on 11 nights in 1995 with 2 to 6 observations recorded on each of those nights. Densities of eggs observed in the photographs were highly variable, reflecting the effects of temporal differences in egg release, current speed and spatial heterogeneity in current regimes. A pattern that was often observed was for eggs to be initially most abundant near the substratum and at mid-depth and then become more common near the surface (Fig. 2A). Total release for the clone at Korbiski (Fig. 2B) was calculated as the product of the egg density, depth of water, width of the zone over which eggs were dispersing, time the eggs were present in the water column, and current speed. On nights with the greatest release, cumulative egg production exceeded $10^{6}$ and totals 

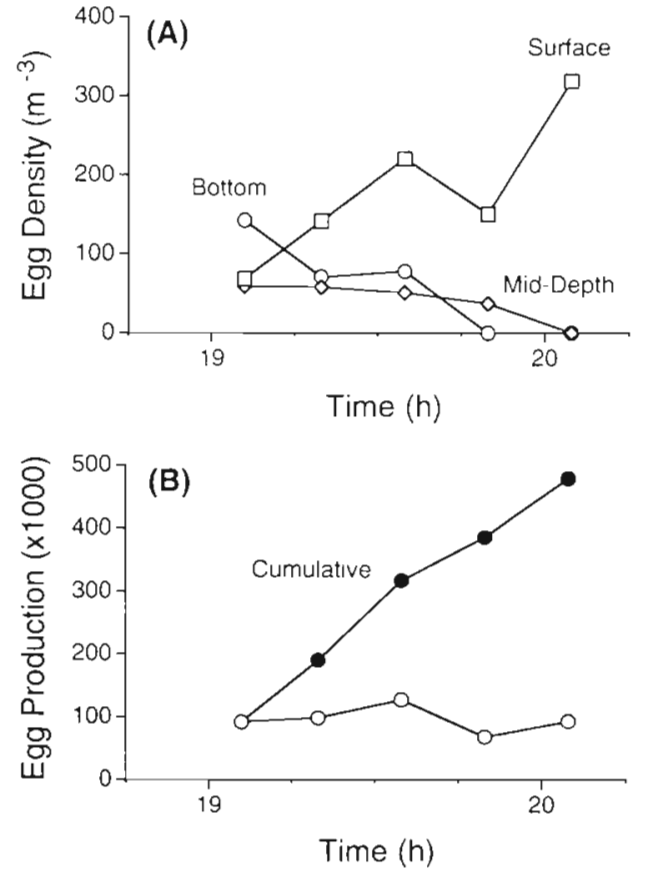

Fig. 2. Plexaura kuna. Egg release by an approximately 800 colony clone during spawning at Korbiski Reef. (A) Egg densities determined photographically for 3 locations in the water column: bottom $(0.3 \mathrm{~m}$ above the substratum), mid-depth ( $1.5 \mathrm{~m}$ above the substratum), and surface $(0.5 \mathrm{~m}$ below the surface). (B) Estimated total egg production by the clone over time $(0)$ and cumulatively $(\bullet)$ over the night (see text for calculation)

over $10^{7}$ when averaged across the 11 nights and extrapolated to $16 \mathrm{~d}$ of spawning ( 4 days in each of 4 months).

\section{Fertilization}

Fertilization rates were highly variable between days (Table 4). The weighted average fertilization rate for 1994 to 1996 was $26.3 \%$, and weighted monthly averages were $32.2,34.8$, and $13.9 \%$ for June, July, and August respectively. There were marginally significant differences between months (1-way ANOVA of arctangent transformed data, days used as replicates, $F=3.22, \mathrm{df}=2,31, \mathrm{p}=0.05$ ).

\section{Larval supply}

Only a single planula was captured in the 45 settlement traps over the duration of their deployment (June to July 1989). The capture occurred in the week following larval release by Plexaura kuna, but the planula could not be identified to species.

\section{Recruitment}

Monthly recruitment rates for Plexaura kuna at the 3 sites were very low. Only 6 possible $P$. kuna recruits were observed in the monthly surveys of the two $1 \mathrm{~m}^{2}$ areas. At Macaroon new recruits were observed in June 1986 and March, June and July 1987. Recruits were observed at Korbiski in July 1986 and March 1987. One recruit was observed at Pinnacles in November 1987. Two of the recruits were first observed in March, 6 mo after spawning. Five of the 6 recruits disappeared between the first and second month after their initial sighting and the sixth disappeared after 2 mo. An additional 36 recruits of other gorgonians were observed. Like the probable $P$. kuna recruits all of the other recruits disappeared after 1 to 5 mo.

Table 4. Plexaura kuna. Fertilization rates of coral eggs collected at Korbiski Reef. Number of eggs collected is indicative of the magnitude released during that night's spawning event

\begin{tabular}{|c|c|c|}
\hline $\begin{array}{l}\text { Date } \\
\text { (yr-mo-d) }\end{array}$ & $\begin{array}{l}\text { No. of eggs } \\
\text { collected }\end{array}$ & $\%$ fertilized \\
\hline $93-07-07$ & 659 & 19.3 \\
\hline $93-07-08$ & 1035 & 48.4 \\
\hline $93-07-09$ & 845 & 60.4 \\
\hline $93-07-10$ & 887 & 44.5 \\
\hline 93-08-05 & 553 & 4.2 \\
\hline $93-08-06$ & 764 & 15.8 \\
\hline $93-08-07$ & 574 & 39.9 \\
\hline $93-08-08$ & 104 & 0.9 \\
\hline $93-08-09$ & 105 & 12.4 \\
\hline $94-06-26$ & 336 & 36.3 \\
\hline $94-06-27$ & 563 & 57.0 \\
\hline $94-06-28$ & 838 & 4.2 \\
\hline $94-06-29$ & 384 & 31.0 \\
\hline $94-06-30$ & 167 & 10.2 \\
\hline $94-07-26$ & 427 & 3.8 \\
\hline $94-07-27$ & 1103 & 23.1 \\
\hline $94-07-28$ & 700 & 24.3 \\
\hline $94-07-29$ & 548 & 77.8 \\
\hline $94-07-30$ & - & - \\
\hline $94-07-31$ & 244 & 0.0 \\
\hline $94-08-27$ & 826 & 12.1 \\
\hline $94-08-26$ & 1197 & 41.3 \\
\hline $94-08-27$ & 1813 & 9.4 \\
\hline $95-06-15$ & 189 & 3.7 \\
\hline $95-06-16$ & 999 & 41.5 \\
\hline $95-06-17$ & 992 & 40.6 \\
\hline $95-06-18$ & 622 & 40.0 \\
\hline $95-07-15$ & 258 & 8.1 \\
\hline $95-07-16$ & 1548 & 35.8 \\
\hline $95-07-17$ & 916 & 20.6 \\
\hline $95-07-18$ & 766 & 38.3 \\
\hline $95-08-13$ & 427 & 0.7 \\
\hline $95-08-14$ & 1317 & 0.4 \\
\hline $95-08-15$ & 1407 & 6.3 \\
\hline $95-08-16$ & 1497 & 16.6 \\
\hline
\end{tabular}


Table 5. Plexaura kuna. Coral recruitment determined from annual censuses at 3 sites in the San Blas Islands. Survey areas were $110 \mathrm{~m}^{2}$ at Macaroon and Pinnacles, and $10 \mathrm{~m}^{2}$ at Korbiski. Values are the total number of new recruits found during each survey

\begin{tabular}{|cccc|}
\hline Year & Pinnacles & Macaroon & Korbiski \\
\hline 1986 & 0 & 0 & 0 \\
1987 & 0 & 0 & 0 \\
1988 & 0 & 0 & 0 \\
1989 & 0 & 1 & 2 \\
1990 & 0 & 0 & 2 \\
1991 & 0 & 0 & 0 \\
1992 & 0 & 0 & 0 \\
1993 & 0 & 0 & 0 \\
1994 & 0 & 0 & 0 \\
1995 & 0 & 1 & 0 \\
1996 & 0 & 0 & \\
\hline
\end{tabular}

Results of the annual survey of the larger areas are reported in Table 5. No Plexaura kuna recruits were observed in the annual censuses at Pinnacles, and annual recruitment rates at the 2 other sites were extremely low. Those values may be even lower given that the identities of the recruits were not certain. Recruits scored as $P$. kuna could have been $P$. flexuosa as they are similar in appearance when they are only a few centimeters tall. In all but 1 instance, the recruits disappeared prior to the second census when it would have been possible to make positive species identifications.

\section{Survival}

Over 2000 planulae were reared and placed in 40 containers in the post-settlement survival experiments in 1991. Only 266 planulae attached to the Plexiglas settlement plates. The remainder either died, attached to the container walls, or never attached. Those that attached and metamorphosed were not distributed randomly with respect to the surface area of the 4 areas on the plates (Fig. 1). Planulae preferentially settled into the center area (Zone $C$ ) and avoided the ridges (Zone R): planulae were 4 times more common in the center of the plate and approximately half as abundant on the ridges than predicted $(\mathrm{G}=192.6$, $\mathrm{df}=3, \mathrm{p}<0.001$ )

There was an additional loss of settled individuals when the plates were transferred out to the field. After $1 \mathrm{~d}$ in the field, there were only 178 individuals distributed on 38 plates. The distribution of those surviving individuals was non-random with respect to the 4 zones on the plate (Fig. 3, G = 74.9, df =3, p<0.001), but the skew toward the center region was not as great

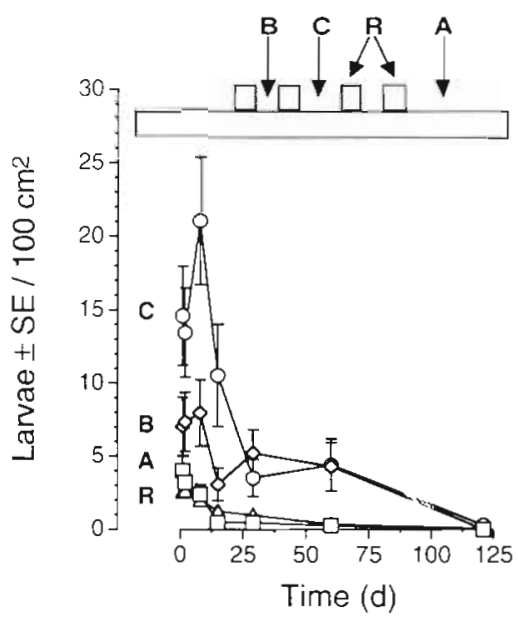

Fig. 3. Plexaura kuna. Numbers of settled polyps found on plates as functions of settlement zone and time after the plates were transferred to the reef. Values are normalized relative to the area of the different zones on the settlement plate. A, B, C and $R$ refer to the zones of the settlement plate as indicated in the schematic diagram above

as in the initial settlement pattern. Disappearance of recruits at that stage was most probably due to their attachment to material that became dislodged during or shortly after transfer to the field. Those disappearances were not considered in any of the subsequent calculations. After deployment in the field the number of polyps per plate ranged from 1 to 14 . On some plates the number identified on the plates increased due to the rediscovery of a polyp that had been scored as missing. Those values were not adjusted in order to incorporate the variance due to experimental error into the regression analysis.

Mortality subsequent to placement of the settlement plates on the reef was high. After 4 mo there were only 3 polyps present and none after 6 mo. During the first 2 mo when the monitoring was most intense, mortality was linear and averaged $3 \% \mathrm{~d}^{-1}$ (Fig. 4). Survivorship was not uniform across the different zones on the plates (test of independence between number of surviving polyps and zone at Days 1, 29 and 60, $\chi^{2}=26.2$, $\mathrm{df}=6, \mathrm{p}<0.001$ ). As shown in Fig. 5, Zone A had the sharpest decline in numbers of individuals. The survivorship data from each area were fitted to log-linear regressions in order to determine per capita daily mortality. Slopes $( \pm \mathrm{SE})$ were $-0.055 \pm 0.010(\mathrm{p}=0.003)$ for Zone $A_{1}-0.030 \pm 0.003(p=0.001)$ for Zone $C$, and $0.029 \pm 0.001(p=0.001)$ for Zone $R$. The variances around the slopes were great but the most exposed area on the plates (i.e. Zone A) had the greatest mortality. The polyps in the least exposed area, Zone $B$, had the lowest overall mortality rate. The non-significant slope $0.011 \pm 0.005(p=0.074)$ suggests that mor- 


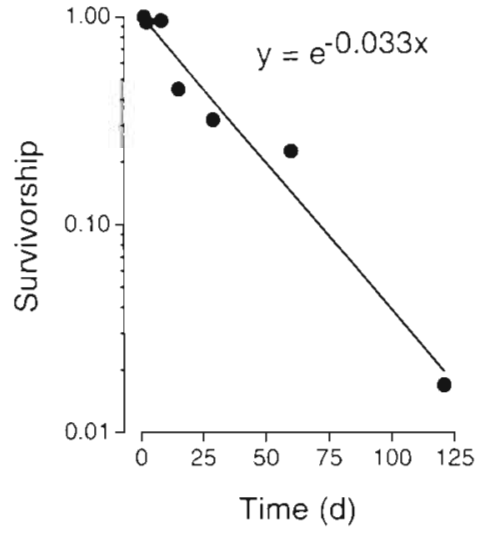

Fig. 4. Plexaura kuna. Survivorship of settled polyps (proportion of the initial cohort remaining) plotted as a function of time after return to the reef

tality was not constant, and the data (Fig. 5) suggest that mortality after the initial few weeks may even be lower than the 0.011 average value.

Settlement and survivorship in the 1995 experiments (Fig. 6) exhibited both similarities and dissimilarities to the 1991 data. A far greater proportion of larvae attached in 1995 (196 of 375). As in 1991, the largest proportion of planulae attached in the center of the plate $(G=259.6$, $\mathrm{d} f=2, \mathrm{p}<0.001)$, but unlike the 1991 experiment survival in the different areas did not differ $(G=1.24, \mathrm{df}=3, \mathrm{p}>0.5)$. Two of the plates suffered catastrophic mortality after $24 \mathrm{~d}$, but with the exception of those 2 points survivorship was linear. Daily mortality was determined from linear regression of natural log transformed survivorship data and yielded mortality rates of $2.8 \% \mathrm{~d}^{-1}$ with a $95 \%$ confidence

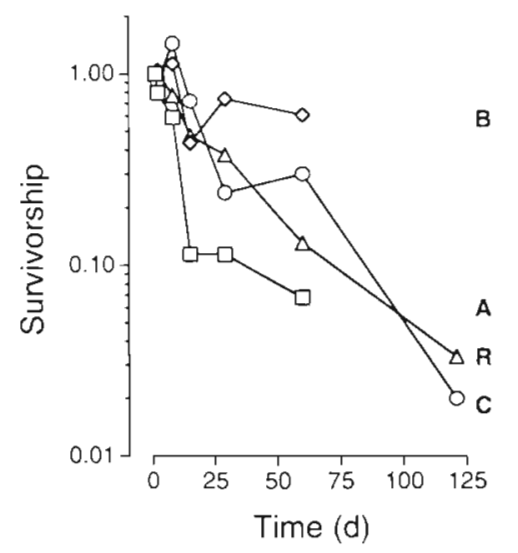

Fig. 5. Plexaura kuna. Survivorship of settled polyps as functions of settlement zone and time after return to the reef. Increases in apparent survivorship are due to the rediscovery of polyps that had previously been scored as missing. Symbols refer to different areas of settlement plate: (a) Zone $A$, $(\diamond)$ Zone B, (o) Zone $C_{,}(\Delta)$ Zone R interval of 2.2 to $3.4 \% \mathrm{~d}^{-1}\left(\mathrm{r}^{2}=0.92\right)$. The 2 points with catastrophic mortality at Day 24 were not included in this analysis. Inclusion of those points raises mortality to $4.75 \% \mathrm{~d}^{-1}\left(\mathrm{r}^{2}=0.97\right)$.

\section{DISCUSSION}

Plexaura kuna densities on reefs in the San Blas Islands vary from 60 to 2000 colonies per reef $(0.67$ to 0.0016 colonies $\mathrm{m}^{-2}$ ) (Coffroth \& Lasker 1998). However, most $P$. kuna colonies develop via vegetative propagation (Lasker 1984, 1990), and the number of genetic individuals detected in DNA fingerprint analyses of those same populations ranges from 3 to $18(1 \times$ $10^{-4}$ to $3 \times 10^{-3}$ genotypes $\mathrm{m}^{-2}$ ) (Coffroth \& Lasker 1998). Most of the colony-level population dynamics are driven by colony growth, survival, and vegetative propagation. Therefore, recruitment and survival of planulae may have little short term effect on species abundance when measured in terms of colonies. However, the presence of multiple genotypes on reefs and the presence of $P$. kuna on many reefs suggest that larval recruitment does occur. The low genotypic diversity of $P$. kuna on these reefs indicates that clones do not 'accumulate' on reefs and it suggests that, in spite of their theoretical immortality, clones go extinct. At the level of genetic individuals, P. kuna is a relatively rare species and its low genotypic diversity on reefs in the San Blas Islands is consistent with the low rate of success in most of the steps leading to recruitment. Nonetheless, on scales of tens and hundreds of years, recruitment of planulae is essential to population survival. Thus, studying the processes controlling the establishment of new genotypes is essential for understanding the long term maintenance of populations, their ability to recover from catastrophic mortality events, and the development of conservation and remediation strategies.

The first step in the recruitment process, the production of eggs, is perhaps the only step in which Plexaura kuna is clearly successful. Whole colony and clone egg production can be extrapolated from both the egg density measurements and data on fecundity, colony size, and clone size. The egg density data suggest that the largest clone at Korbiski, which contained approximately 800 colonies (Coffroth \& Lasker 1998), produced $10^{7}$ eggs annually. Although those estimates are based on extrapolations of a relatively small number of density measurements, similar values can be obtained from extrapolations of fecundity and colony morphology data. Lasker (1990) related colony size (total length of all branches) and colony height for small colonies. $P$. kuna (Fig. 1 in Lasker 1990) exhibited a height dependent upper limit to size, and extrapolation of those data 
suggests that colonies greater than $100 \mathrm{~cm}$ in height can contain $10^{3}$ linear $\mathrm{cm}$ of living tissue. Similar results were found for branches we used in the aquaria; these branches were typically 100 to $200 \mathrm{~cm}$ in total length and usually contained a $4^{\circ}$ branch. Large colonies (75 to $150 \mathrm{~cm}$ in height) contain 10 to $204^{\circ}$ branches (Lasker unpubl. data) and by extrapolation can have 1000 to $4000 \mathrm{~cm}$ of tissue. Using a mean fecundity of 23.2 eggs $\mathrm{cm}^{-1}$ (from Table 2), large colonies are estimated to produce $10^{4}$ eggs. Given that $P$. kuna genets are made up of 1 to 800 colonies (Coffroth et al. 1992, Coffroth \& Lasker 1998), genotypelevel production can range from $10^{4}$ to $10^{7}$ eggs each year. Genet-level annual productivity of up to $10^{7}$ eggs for $P$. kuna is greater than that of aclonal species such as Paramuricea clavata (Coma et al. 1995) and Euniciella stricta (Theodor 1967), and enables P. kuna clones to equal and perhaps exceed the productivity of species that form very large colonies such as Pseudoplexaura spp. (Coma \& Lasker 1997). The 1 to 2 order of magnitude difference between the reproductive output of a single colony and a clone demonstrates one of the advantages of clonal reproductive strategies.

We also found that $2^{\circ}$ branches had greater numbers and volumes of eggs than either $1^{\circ}$ or $3^{\circ}$ branches. Possible causes for the increase include tradeoffs between growth at branch tips and reproduction, and possibly age of the polyps. Regardless of the cause, these differences affect estimates of fecundity that are based on extrapolations from polyp dissections. Because the explants used in our aquarium collections contained branches of different branch order in their naturally occurring ratios, our egg release data integrated the effects of the different branch orders. Extrapolations from single branches should be based on $1^{\circ}$ branches because the geometric branching patterns of $P$. kuna colonies (Brazeau \& Lasker 1988) produce colonies with biomass dominated by $1^{\circ}$ branches.

Although Plexaura kuna genets produced prodigious numbers of gametes during spawning, the subsequent steps in the recruitment process dramatically lowered recruitment success. Over half of the eggs did not develop into planulae, and on some nights the fertilization rate approached $0 \%$ (Table 4 ; Lasker et al. 1996a). This is consistent with the low supply and recruitment rates observed at Korbiski, but the zygote production data cannot be directly compared to the supply. The patchy distribution of P. kuna in the San Blas Point region as well as variable currents (Lasker \& Kapela 1997) make it impossible to predict both source areas for recruitment to our study reefs and where eggs released in our study area went. As planulae do not settle for 3 d or more (Lasker \& Kim 1996), recruits to the reefs may have come from populations tens to hundreds of kilometers away. The presence of complex tidally driven flows in the San Blas Point region (Lasker \& Kapela 1997, authors' pers, obs.) leaves open the possibility that there is some local retention of larvae and some self-seeding of reefs.

The supply of larvae onto the reef at Korbiski was low. The single planula captured across 45 settlement tubes over a period of $7 \mathrm{wk}$ is several orders of magnitude lower than many of the supply rates of barnacles observed by Yund et al. (1991). Capture efficiencies of larval traps differ as a function of size, buoyancy, and behavior of the larvae (Yund et al. 1991), making it difficult to compare the Plexaura kuna data with supply rates for other taxa. However, the very low supply rates are consistent with both our annual and monthly recruitment observations (Tables 4 \& 5)

Finally, once settled, polyps on our settlement plates were subject to high mortality. The plates are an artificial substratum and probably did not offer the full range of micro-habitats available to settling planulae in nature. However, the settlement plates developed heavy growths of coralline algae and encrusting invertebrates, and, at the time of their removal from the field for our experiments, the plates were visually similar to the natural substratum on which they had been attached. The few naturally occurring recruits that we observed in the survey areas did not settle on substrata notably different from those present on the settlement plates.

Mortality of the settled recruits was not uniform across all areas of the settlement plate in the 1991 experiments (Fig. 5). Mortality in the narrow groove between the 2 ridges, Zone $B$, was the lowest and nonlinear, leveling off after an initial drop in the first $2 \mathrm{wk}$. This result is similar to that for the bryozoan Bugula neritina, which exhibits high but decreasing mortality rates during the first several post-settlement weeks (Keough \& Chernoff 1987). Decreasing mortality with colony size is a common pattern among colonial organisms (Connell 1973, Hughes \& Connell 1987, Lasker 1990) but, because Plexaura kuna recruits did not develop beyond single polyp stage in the course of the study, the patterns of mortality are likely due to the quality of the refuge afforded by the different settlement zones on the plate. This suggestion is corroborated by the 1995 experiments in which the entire plate was floated above the substratum and was somewhat protected from grazers and browsers. In that experiment, mortality rate was lower than in the 1991 experiment, declining mortality was not observed, and there were no differences in mortality rates between settlement zones (Fig. 6). Overall, the high mortality of polyps on the settlement plates in the 1991 experiments was also consistent with mortality of the larger natural recruits that we observed. All of the natural recruits observed in the monthly surveys disappeared 


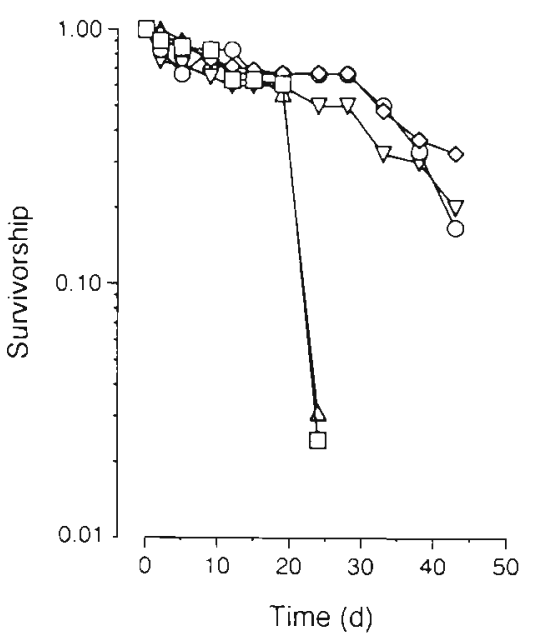

Fig. 6. Plexaura kuna. Survivorship of settled polyps as a function of time during the 1995 experiment. In this experiment, the settlement plates were floated off the substratum. Fates of polyps on individual settlement plates $(n=5)$ are shown as separate lines; symbols refer to different settlement plates

within several months, and, in $12 \mathrm{yr}$ of observations, we have only once observed a recruit in the annual censuses that survived over a year.

Post-settlement mortality at the average rate observed on the settlement plates makes successful recruitment extraordinarily unlikely. This can be seen if we consider a female genet producing eggs that must be successfully fertilized, survive in the water column, and settle and survive on suitable substratum on a reef. The observed mortality on the settlement plates (post-settlement mortality) was $3 \% \mathrm{~d}^{-1}$ or an annual survival of approximately $10^{-6}$. At that rate, expectations based on a Poisson probability distribution are that settlement of 700000 ind $\mathrm{yr}^{-1}$ is necessary in order to produce a single successful recruitment event $95 \%$ of the time (i.e. 1 recruit or more will be found in 19 of 20 years), and 11000 larvae must settle each of 20 years to yield a single successful recruit in 1 of those 20 years. In order to generate 11000 settling larvae, the planulae from a female genet that released $10^{7}$ eggs and had $25 \%$ fertilization rates would require a survival rate in the water column of $10^{-3}$. In comparison, a single colony releasing $10^{4}$ eggs would require almost total survival of its zygotes while they were in the water column. Planulae spend at least $3 d$ in the water column (Lasker \& Kim 1996), and survivorship of $10^{-3}$ or better is probably an optimistic value for the fate of larvae in the water column.

At an average post-settlement mortality of $3 \% \mathrm{~d}^{-1}$, successful reproduction (i.e. survival through to recruitment) is extremely unlikely, and successful reproduction may rely on circumstances in which production, fertilization and/or survival of gametes are unusually enhanced. The differences in survival of settlers on different substrata may provide such an opportunity. Survival rates have exponential effects on reproductive success. Therefore, recruitment rates are more sensitive to changes in survival than to changes in either fecundity or fertilization, whose effects on recruitment are linear. The protected area, Zone $B$, only had $1.1 \%$ mortality $\mathrm{d}^{-1}$, which is equivalent to $1 \mathrm{yr}$ survivorship of $10^{-2}$ Using the same Poisson based probabilities discussed above, settlement of 170 planulae $\mathrm{yr}^{-1}$ would yield predictable recruitment (i.e. a $95 \%$ probability of a single surviving recruit each year), and as few as $3 \mathrm{yr}^{-1}$ would produce a recruit in at least 1 of every 20 years. In this scenario a cohort of $10^{7}$ eggs could yield recruits with water column survival rates as low as $10^{-5}$ or $10^{-7}$. Plexaura kuna preferentially settled into Zone $B$ in the experiments (this study) and also preferentially settled when rubble containing crustose coralline algae was present (Lasker \& Kim 1996). These 2 features may enhance survival of settling planulae in nature and may have made possible the few recruits we observed in the San Blas Islands.

Some dramatically high recruitment rates have been reported among scleractinians (Sammarco \& Andrews 1988, 1989, Fisk \& Harriott 1990, Sammarco 1991, Maida et al. 1995). However, exceptionally low recruitment rates among clonal coral reef species like Plexaura kuna are also common. For example, abundant and often dominant species such as the Montastrea annularis complex are notably absent from recruitment surveys (Rylaarsdam 1983, Rogers et al. 1984, Smith 1992, Witman 1992). Perhaps more surprising, taxa that exhibit a dramatic ability to colonize substrata vegetatively and appear to have more opportunistic life history strategies, such as the alcyonacean Efflatounaria sp. or the zoanthid Zonathus sp., have very low rates of sexual recruitment (Karlson et al. 1996 and Karlson 1983, respectively). Indeed, life history strategies of clonal taxa may simultaneously incorporate traits commonly associated with both density dependent and independent selection (Karlson et al. 1996). P. kuna relies on a growth strategy that generates large and long-lived genets, resulting in colonylevel population dynamics that are virtually independent of sexual recruitment (Coffroth \& Lasker 1998). Nonetheless, persistence of species such as $P$. kuna is dependent on the colonization and recolonization of areas by sexual recruits. Although the probability of a genet replacing itself is extraordinarily small in any one year, our data indicate that successful reproduction, settlement, and growth may be assured when considered over the decades and longer lifespans of colonies and genets. Similarly, the extended lifespan of $P$. kuna clones makes it more likely that a genet will reproduce during a year with uncharacteristically high 
survival either in the water column or after settlement. In 12 yr of monitoring reefs in the San Blas Islands we have observed such recruitment events among both Pseudopterogorgia sp. and Pseudoplexaura porosa populations.

Clonal propagation, by increasing the size and longevity of genets, enhances lifetime fecundities to levels at which persistence of populations may increase from seemingly impossible to probable. However, recruitment rates among taxa like Plexaura kuna will be more sensitive to water column and post-settlement survival than to production and fertilization. Thus, the greatest advantage of clonal propagation may be to extend life spans such that a genet will reliably have the opportunity to reproduce during one of the rare years in which water column and/or post-settlement survival are high.

Acknowledgements. Work in the San Blas lslands was assisted by Elizabeth Beiring, Julio Calderon, Rafel Coma, Walter Kapela, Kristin Kittle, Milton Moreno, Bron Sinclair, and Tim Swain. Richard Meyer assisted with laboratory analyses of egg densities. Reynaldo Tapia, station manager of the STRI San Blas station, and numerous other STRI staff and scientists made our work more productive and pleasant. We thank the Kuna Indians and the Republic of Panama for permission to work in the San Blas. We also thank Elizabeth A. Beiring and 3 anonymous reviewers for comments on the manuscript. The research has been supported by grants from the National Geographic Society and the National Science Foundation (OCE 9217014).

\section{LITERATURE CITED}

Babcock RC (1991) Comparative demography of three species of scleractinian corals using age- and size-dependent classifications. Ecol Monogr 61:225-244

Babcock R, Mundy C (1996) Coral recruitment: consequences for settlement choice for early growth and survivorship in two scleractinians. J Exp Mar Biol Ecol 206:179-201

Benayahu Y, Loya Y (1984) Substratum preference and planulae settling of two Red Sea alcyonaceans: Xenia macrospiculata Gohar and Parerythropodium fulvum fulvum (Forskål). J Exp Mar Biol Ecol 83:249-261

Brazeau DA, Lasker HR (1988) Inter- and intraspecific variat.on in gorgonian colony morphology: quantifying branching patterns in arborescent animals. Coral Reefs 7 . $139-143$

Brazeau DA, Lasker HR (1989) Reproductive cycle and larval release of a Caribbean gorgonian. Biol Bull (Woods Hole) 176:1-7

Brazeau DA, Lasker H (1990) Sexual reproduction and external broocting by the Caribbean gorgonian Briareum asbestinum. Mar Biol 104:465-474

Brazeau DA, Lasker HR (1992) Reproductive success in a marine benthic invertebrate, the Caribbean octocoral Briareum asbestinum. Mar Biol 114:157-163

Butman CA, Starczak VR, Pawlik JR (1992) Hydrodynamic facilitation of gregarious settlement of a reef-building tube worm. Science 251:421-424

Carlon DB, Olson RR (1993) Larval dispersal distance as an explanation for adult spatial pattern in two Caribbean reef corals. J Exp Mar Biol Ecol 173:247-263
Chabot R, Bourget E (1988) Influence of substratum heterogeneity and settled barnacle density of the settlement of cyprid larvae. Mar Biol 97:45-56

Coffroth MA, Lasker HR (1998) Population structure of a clonal gorgonan coral: the interplay between clonal reproduction and disturbance. Evolution (in press)

Coffroth MA, Lasker HR, Diamond ME, Bruenn JA, Bermingham $E$ (1992) DNA fingerprints of a gorgonian coral: a method for detecting clonal structure in a vegetative species. Mar Biol 114:317-325

Coles SL (1984) Colonization of Hawaiian reef corals on new and denuded substrata in the vicinity of a Hawaiian power station. Coral Reefs 3:123-130

Coma R, Lasker HR (1997) Spatial and temporal variability in in situ fertilization in a broadcast spawning invertebrate. Biol Bull (Woods Hole) 193:20-29

Coma R, Zabala M, Gili JM (1995) Sexual reproductive effort in the Mediterranean gorgonian Paramuricea clavata. Mar Ecol Prog Ser 117:185-192

Connell JH (1973) Population ecology of reef building corals. In: Jones O, Endean R (eds) Biology and geology of coral reefs. Academic Press, New York, p 205-245

Connell JH (1985) The consequences of variation in initial settlement vs. post-settlement mortality in rocky intertidal communities. J Exp Mar Biol Ecol 93:11-45

Davis AR (1988) Effects of variation in initial settlement on distribution and abundance of Podocalvella moluccensis Sluiter. J Exp Mar Biol Ecol 117:157-167

Eckman JE (1987) The role of hydrodynamics in recruitment, growth, and survival of Argopecten irradians (L.) and Anomia simplex (D'Orbigny) within eelgrass meadows J Exp Mar Biol Ecol 106:165-191

Eckman JE (1990) A model of passive settlement by planktonic larvae onto bottoms of differing roughness. Limnol Oceanogr 35:887-901

Eckman JE (1996) Closing the larval loop: linking larval ecology to the population dynamics of marine benthic inverte brates. J Exp Mar Biol Ecol 200:207-237

Fabricius KE (1995) Slow population turnover in the soft coral genera Sinularia and Sarcophyton on mid-and outer-shelf reefs of the Great Barrier Reef Mar Ecol Prog Ser 126 $145-152$

Fadlallah YH (1983) Population dynamics and life history of a solitary coral, Balanophyllia elegans, from central California. Oecologia 58:200-207

Fisk DA, Harriot VJ (1990) Spatial and temporal variation in coral recruitment on the Great Barrier Reef: implications for dispersal hypotheses. Mar Biol 107:485-490

Gaines S, Roughgarden J (1985) Larval settlement rate. Proc Nat Acad Sci USA 82:3707-3711

Grosberg RK (1982) Intertidal zonation of barnacles: the influence of planktonic zonation of larvae on vertical distribution of adults, Ecology 63:894-899

Harriott VJ (1983) Reproductive ecology of four scleractinian species at Lizard Island, Great Barrier Reef. Coral Reefs $2: 9-18$

Hughes TP, Connell JH (1987) Population dynamics based on size or age? A reef-coral analysis. Am Nat 129:818-829

Hunte W, Wittenberg M (1992) Effects of eutrophication and sedimentation on juvenile corals. II. Settlement. Mar Biol $114: 635-631$

Hurlbut CJ (1991) Community recruitment: settlement and juvenile survival of seven co-occurring species of sessile marine invertebrates. Mar Biol 109:507-515

Karlson RH (1983) Disturbance and monopolization of a spatial resource by Zoanthus sociatus (Coelenterata, Anthozoa). Bull Mar Sci 33:118-131 
Karlson RH, Hughes TP, Karlson SK (1996) Density-dependent dynamics of soft coral aggregations: the significance of clonal growth and form. Ecology 77:1592-1599

Keough MJ, Chernoff M (1987) Dispersal and population variation in the bryozoan Bugula neritina. Ecology 68:199-210

Keough MJ, Downes BJ (1982) Recruitment of marine invertebrates: the role of active larval choices and early mortality. Oecologia 54:348-352

Lasker HR (1984) Asexual reproduction, fragmentation, and skeletal morphology of a plexaurid gorgonian. Mar Ecol Prog Ser 19:261-268

Lasker HR (1990) Clonal propagation and population dynamics of a gorgonian coral. Ecology 71:1578-1589

Lasker HR, Brazeau DA, Calderon J, Coffroth MA, Coma R, Kim K (1996a) In situ rates of fertilization among broadcast spawning gorgonian corals. Biol Bull (Woods Hole) 190: $45-55$

Lasker HR, Coffroth MA (1985) Vegetative reproduction, clonal spread, and histocompatibility in a Caribbean gorgonian. Proc 5th Int Coral Reef Symp 4:331-336

Lasker HR, Coffroth M, Fitzgerald L (1988) Foraging patterns of Cyphoma gibbosum on octocorals: the roles of host choice and feeding preference. Biol Bull (Woods Hole) $174: 254-266$

Lasker HR, Kapela WJ (1997) Heterogeneous water flow and its effects on the mixing and transport of gametes. In: Lessios HA, Macintyre $1 \mathrm{G}$ (eds) Proc 8th Int Coral Reef Symp, Vol 2. Smithsonian Tropical Research Institute, Balbao, Panama, p 1109-1114

Lasker HR, Kim K (1996) Larval development and settlement behavior of the gorgonian coral Plexaura kuna (Lasker, Kim and Coffroth). J Exp Mar Biol Ecol 215:49-64

Lasker HR, Kim K, Coffroth MA (1996b) Reproductive? and genetic variation among Caribbean gorgonians: the differentiation of Plexaura kuna, a new species. Bull Mar Sci 58:277-288

Levitan DR (1993) The importance of sperm limitation to the evolution of egg size in marine invertebrates. Am Nat 141:517-536

Levitan DR (1995) The ecology of fertilization in free-spawning invertebrates. In: McEdwards L (ed) Ecology of marine invertebrate larvae. CRC Press, Boca Raton, p 123-156

Levitan DR, Petersen $C$ (1995) Sperm limitation in the sea. Trends Ecol Evol 10:228-231

Maida M, Sammarco PW, Coll JC (1995) Effects of soft corals on scleractinian coral recruitment. I: directional allelopathy and inhibition of settlement. Mar Ecol Prog Ser 121. $191-202$

Morse ANC, Iwao K, Baba M, Shimoike K, Hayashibara T, Omori $M$ (1996) An ancient chemosensory mechanism brings new life to coral reefs. Biol Bull (Woods Hole) 191: $149-154$

Morse DE (1990) Recent progress in larval settlement and metamorphosis: closing the gaps between molecular biology and ecology. Bull Mar Sci 46:465-483

Morse DE, Hooker N, Morse ANC, Jensen RA (1988) Control of larval metamorphosis and recruitment in sympatric agariciid corals. J Exp Mar Biol Ecol 116:193-217

Editorial responsibılity: Ron Karlson (Contributing Editor), Newark, Delaware, USA
Morse DE, Morse ANC, Raimondi PT, Hooker N (1994) Morphogen-based chemical flypaper for Agancla humilis coral larvae. Biol Bull (Woods Hole) 186:172-181

Mullineaux LS (1989) Vertical distribution of the epifauna on manganese nodules: implication for settlement and feeding. Limnol Oceanogr 34:1247-1262

Mullineaux LS, Garland ED (1993) Larval recruitment in response to manipulated field flows. Mar Biol 116:667-683

Pawlik JR, Toonen RJ (1992) Foundations of gregariousness. Nature 370:511-512

Pennington JT (1985) The ecology of fertilization of echinoid eggs: the consequences of sperm dilution, adult aggregation, and synchronous spawning. Biol Bull (Woods Hole) 169:417-430

Robertson DR (1987) Responses of two coral reef toadfishes (Batrachoidudae) to the demise of their primary prey, the sea urchin Diadema antillarum. Copeia 3:637-642

Rogers CS, Fitz HC, Gilnack M, Beets J, Hardin J (1984) Scleractinian coral recruitment patterns at Salt River submarine canyon, St Croix, US Virgin Islands. Coral Reefs $3: 69-76$

Rylaarsdam KW (1983) Life histories and abundance patterns of colonial corals on Jamaican reefs. Mar Ecol Prog Ser 13:249-260

Sammarco PW (1991) Geographically specific recruitment and postsettlement mortality as influences on coral communities: the cross-continental shelf transplant experiment. Limnol Oceanogr 36:496-514

Sammarco PW, Andrews JC (1988) Localized dispersal and recruitment in Great Barrier Reef corals: the Helix experiment. Science 239:1422-1424

Sammarco PW, Andrews JC (1989) The Helix experiment: differential localized dispersal and recruitment patterns in Great Barrier Reet corals. Limnol Oceanogr 34:896-912

Sebens KP (1983) Settlement and metamorphosis of a temperate soft-coral larva (Alcyonium siderium Verrill): induction by crustose algae. Biol Bull (Woods Hole) 165:286-304

Smith SR (1992) Patterns of coral recruitment and post-settlement mortality on Burmuda's reefs: comparison to Caribbean and Pacific Reefs. Am Zool 32:663-673

Theodor J (1967) Contribution à l'étude de gorgones (VII): écologie et comportement de la planula. Vie Milieu 18: 291-301

Wethey DS (1984) Spatial pattern in barnacle settlement: day to day changes during the settlement season. J Mar Biol Assoc UK 64:687-698

Wethey DS (1986) Ranking of settlement cues by barnacle larvae: influence of surface contour. Bull Mar Sci 39:393-400

Witman JD (1992) Physical disturbance and community structure of exposed and protected reefs: a case study from St. John, U.S. Virgin Islands. Am Zool 32:641--654

Young CM (1990) Larval ecology of marine invertebrates: a sesquicentennial history. Ophelia 32:1-48

Yund PO. Cunningham CW, Buss LW (1987) Recruitment and post-recruitment interactions in a colonial hydroid. Ecology 68:971-982

Yund PO. Gaines SD, Bertness MD (1991) Cylindrical tube traps for larval sampling. Limnol Oceanogr 36:1167-1177

Submitted: August 27, 1997; Accepted: November 26, 1997 Proofs received from author(s): January 26, 1998 